NOTICIAS

Rev Chil Salud Pública 2013

Vol 17 (1): 101

\title{
Miguel Kottow: maestro de la bioética chilena
}

\author{
Miguel Kottow: \\ Distinguished Scholar of Chilean Bioethics
}

El día martes 19 de marzo, en el Auditorio Departamento de Bioética, le fue concedida por la Sociedad Chilena de Bioética, la distinción «Maestro de la Bioética Chilena» al Dr. Miguel Kottow Lang.

El profesor Kottow es uno de nuestros más laboriosos miembros en la trastienda, de la cual emerge en ocasiones. Miembro del actual comité editorial en construcción, es además un colaborador entusiasta y puntual, revisor infatigable de libros, articulista cuidadoso del estilo, que siempre nos sorprende con nuevos tropos, palabras e ideas, editorialista invitado cuando la ocasión lo merece, revisor de pares comprometido, interlocutor anónimo de gran parte de nuestros textos, ideas y propuestas. Como compañero de equipo entonces, compartimos con alegría la noticia de este reconocimiento.

En su conferencia Albañiles de Babel desarrollada en la ocasión, Miguel abordó la dificultad contemporánea para producir una ética común:

"Si fuese posible sintetizar sin reduccionismo, podría plantearse la ética actual en términos del enfrentamiento entre religiosidad, impensable sin fundarse en verdades absolutas, y secularidad dependiente de una racionalidad que, siendo analitica, se engolosina y finalmente intoxica e inmoviliza con tanta pluralidad.»

Al trabajo en esa perspectiva lo llamó una labor constructiva y de allí el título y la alusión al frustrado esfuerzo de construir un lugar común, una atmósfera. Recordó que el fracaso de Babel fue causado por la introducción de lenguas diversas, pero alentó el propósito original y lo reanimó en la actualidad moderna. Avanzando entre sus afinidades electivas en la bioética relacional y comunicacional, y sus actuales ocupaciones con el bioederecho, Kottow llamó a construir ese encuentro, buscando en el tronco y no las ramas. Troncos que propuso como relacionalidad y trascendencia.

Su conferencia terminó con una propuesta acerca del bioética, erguida como bandera de paz, que sin cerrar el debate, permita iniciar las conversaciones entre bandos:

"Las siempre respetadas pero disputadas e incumplidas proclamas sobre la dignidad $y$ los derechos del ser humano nos han entrampados en disputas e indeterminaciones por cuanto han sido incapaces de situarnos en una perspectiva común. Termino con la temeridad de sugerir un puente más universal en un nuevo intento de construir la Torre de Babel: La bioética delibera sobre relacionalidad y trascendencia comprometidos por intervenciones sobre procesos vitales y naturales».

La propuesta del cierre de su charla, el propósito de identificar tareas centrales en un arco de propuestas siempre más variadas, es de aquellas que Sloterdijk propone encarar: «La auténtica comunidad de esfuerzo consiste, en el futuro, en seres humanos en proceso de aprendizaje, de las culturas más diferentes, que no se entreguen tanto al desencadenamiento de energía entre sus grupos, cuanto a aislar las situaciones que reclaman ese desencadenamiento». 